\title{
IMPLEMENTASI METODE CARD SORT UNTUK MENINGKATKAN AKTIVITAS BELAJAR PADA MATA PELAJARAN IPA SISWA KELAS VII SMPN 31 BATAM
}

\section{IMPLEMENTATION OF CARD SORT METHOD TO INCREASE ACTIVITY IN LEARNING STUDENT SUBJECT SCIENCE (IPA) CLASS VIII SMPN 31 BATAM}

\author{
Darlianty $^{1}$, Lani Puspita ${ }^{2}$, Destaria Sudirman ${ }^{2}$ \\ ${ }^{1}$ Alumni Program Studi Pendidikan Biologi, FKIP, Universitas Riau Kepulauan, Batam \\ ${ }^{2}$ Dosen Program Studi Pendidikan Biologi, FKIP, Universitas Riau Kepulauan, Batam
}

Koresponden: lanipuspita@gmail.com

\begin{abstract}
Abstrak
Penelitian ini merupakan penelitian tindakan (Penelitian Tindakan Kelas), yang meliputi perencanaan, pelaksanaan, observasi dan refleksi. Tujuan penelitian ini adalah untuk mengetahui sejauh mana penerapan metode Card Sort dapat meningkatkan aktivitas belajar siswa kelas VII B pada pembelajaran IPA Terpadu (sains) di SMP N 31 Batam di Tahun Akademik 2013/2014. Pelaksanaan penelitian ini berlangsung 3 (tiga) siklus setiap siklus dilakukan dua pertemuan dan satu pertemuan pada siklus ketiga. Hasil penelitian menunjukkan bahwa peningkatan kegiatan belajar siswa dengan rata-rata pada siklus 1 adalah 57\% (rendah), pada siklus 2 adalah 101\% (tinggi) dan siklus 3 adalah 121\% (sangat tinggi). Aktivitas guru rata-rata pada siklus pertama adalah $75 \%$ (kurang sempurna), pada siklus kedua adalah $101 \%$ (sempurna) dan siklus ketiga adalah $110 \%$ (sangat sempurna). Dengan demikian penerapan metode Card Sort pada materi sains dapat mempengaruhi peningkatan nilai pada siswa dalam kegiatan belajar baik secara individual maupun kelompok.
\end{abstract}

Kata Kunci: Metode Card Sort, IPA (Sains), Nilai Hasil Belajar

\begin{abstract}
This research is an action research (Class Action Research), which includes planning, implementation, observation and reflection. The purpose of this study was to determine the extent to which the implementation of Card Sort method can increase the activity of students of class VII B on learning Integrated Science (IPA) in SMP N 31 Batam in the academic year 2013/2014. Implementation of this study lasted three (3) cycles each cycle two meetings and one meeting on the third cycle. The results showed that the improvement of student learning activities with an average in first cycle was $57 \%$ (low), the second cycle was 101\% (high) and the third cycle was $121 \%$ (very high). The points of activities average teacher in the first cycle was $75 \%$ (less than perfect), the second cycle was $101 \%$ (perfect) and the third cycle was $110 \%$ (perfect). The implementation of methods Card Sort in material science can impacted the increase in value of the students in learning activities, either individually or in groups.
\end{abstract}

Keywords: Method of Card Sort, Learning Life Science, Learning outcomes

\section{PENDAHULUAN}

Penyusunan kurikulum yang berlaku nasional dan lokal sesuai dengan kepentingan serta jenis pendidikan secara professional. Dalam belajar, seseorang 
dipengaruhi oleh banyak faktor, karena dalam keseluruhan proses belajar mengajar terjadi hubungan timbal balik antara berbagai unsur di sekolah. Faktor eksternal yang mempengaruhi belajar diantaranya faktor guru, faktor teman dan faktor orang tua murid. Sementara pada faktor internal di antaranya faktor minat, motivasi, kebiasaan, kreativitas, perhatian emosional dan lain-lain. Khusus dalam penelitian ini yang akan dijabarkan adalah tentang kreativitas guru dan minat belajar murid.

Aktivitas belajar merupakan segala kegiatan yang dilakukan dalam proses interaksi (guru dan siswa) dalam rangka mencapai tujuan belajar. Aktivitas yang dimaksud adalah ditekankan pada siswa, sebab dengan adanya aktivitas siswa dalam proses pembelajaran terciptalah situasi belajar yang aktif. Satu faktor penting yang mempengaruhi belajar dan hasil belajar seseorang yaitu memiliki aktivitas dengan mencurahkan segala kemampuannya akan mendapatkan hasil belajar yang optimal dan hasil belajar yang diharapkan. Semakin tinggi aktivitas yang dimiliki siswa akan semakin meningkat hasil belajarnya, tetapi kuat dan lemahnya aktivitas seseorang berbeda. Hal ini dipengaruhi oleh faktor cita-cita atau aspirasi, kemampuan belajar, kondisi siswa, dalam membelajarkan siswa. Berdasarkan observasi terlihat di kelas VII B SMP Negeri 31 Batam, dimana kurangnya perhatian murid pada saat guru menjelaskan materi pelajaran, banyaknya siswa yang keluar masuk di saat proses belajar mengajar berlangsung, adanya siswa yang melamun saat guru menjelaskan materi, serta adanya murid yang bingung mengerjakan pekerjaan rumah pada pembelajaran biologi.

Aktivitas siswa adalah keterlibatan siswa dalam bentuk sikap pikiran, proses belajar mengajar dan memperoleh manfaat dari kegiatan tersebut. Peningkatan aktivitas siswa, yaitu meningkatnya jumlah siswa yang terlibat aktif belajar, meningkatnya jumlah siswa bertanya dan menjawab, meningkatnya jumlah yang saling berinteraksi membahas materi pembelajaran. Metode belajar mengajar yang bersifat partisipatoris yang dilakukan guru akan mampu membawa siswa dalam situasi yang lebih kondusif, karena siswa lebih berperan dan lebih terbuka serta sensitive dalam kegiatan belajar mengajar. Indikator aktivitas belajar siswa dapat dilihat dari : mayoritas siswa beraktivitas dalam pembelajaran, aktivitas pembelajaran didominasi oleh kegiatan siswa. Metode akan menunjukkan kondisi pembelajaran yang bagaimana dan apa hasil pembelajaran Biologi yang diharapkan. Cara penyampaian guru seperti ini cenderung tidak melibatkan siswa secara aktif. Konsep-konsep Biologi yang disampaikan masih 
kurang dipahami oleh siswa, hal ini terlihat dari nilai harian siswa pada mata pelajaran Biologi memperoleh nilai rata-rata sebesar 58,4 pada tahun ajaran 2012-2013. Jika siswa mengikuti suatu metode pembelajaran maka nilai harian siswa rata-rata 78.5. Dari data di atas dapat disimpulkan bahwa siswa diharapkan aktif mengikuti metode yang akan diterapkan karena mata pelajaran biologi ini cukup sulit. Banyak jenis metode pembelajaran yang dapat merangsang siswa untuk lebih aktif dalam proses belajar mengajar, salah satu diantaranya adalah metode card sort (media kartu). Metode Card Sort merupakan "suatu strategi yang digunakan pendidik dengan maksud mengajak peserta didik untuk menemukan konsep dan fakta melalui klasifikasi materi yang dibahas dalam pembelajaran" (Fatah, 2008). Untuk menggunakan metode Card Sort, agar tercapai sebaiknya menggunakan pembagian kelompok. Adapun tujuan dari penelitian tindakan kelas ini adalah : Untuk mengetahui peningkatan aktivitas belajar pada materi ekosistem melalui penggunaan metode Card Sort pada siswa kelas VII B SMP Negeri 31 Batam.

\section{METODOLOGI}

Penelitian ini menggunakan teknik penelitian Tindakan Kelas (PTK) yang merupakan penelitian yang dilakukan dengan menggunakan lembar aktivitas guru dan siswa. Penelitian Tindakan Kelas dengan menggunakan metode Card Sort ini dilakukan dalam 5 bulan, yaitu dari bulan Maret 2014 sampai dengan Juli 2014 yang bertempat di SMPN 31 Batam. Subjek penelitian adalah siswa kelas VII B dengan jumlah 25 siswa yang terdiri dari 13 laki-laki dan 12 perempuan. Penelitian direncanakan sebanyak 3 siklus, setiap siklus dilaksanakan dengan dua kali pertemuan dan untuk siklus 3 satu kali pertemuan. Untuk setiap siklus terdiri dari empat tindakan yakni: Perencanaan, Pelaksanaan, Observasi, dan Refleksi. masing-masing untuk siklus I, 2 kali pertemuan. Untuk siklus II, 2 kali pertemuan dan siklus III, 1 kali pertemuan. Pada siklus 1 yaitu menjelaskan konsep Keanekaragaman Makhluk Hidup dan Upaya Pelestariannya. Sedangkan pada siklus 2 menjelaskan Pengaruh Kepadatan Populasi Manusia Terhadap Lingkungan. Dan pada siklus ke 3 mengatasi Pencemaran dan Kerusakan Lingkungan. Pelaksanaan ini menggunakan media kartu untuk menumbuhkan aktivitas belajar siswa dalam pembelajaran dan guru berperan sebagai fasilitator dan siswa belajar secara aktif dengan falilitas dan arahan dari guru. Guru yang akan menjadi observer pada penelitian ini ada dua orang guru wali kelas VII B, bidang studi Bahasa Indonesia dan guru wali kelas VII C bidang studi Biologi. 


\section{PEMBAHASAN}

Berdasarkan hasil penelitian siklus I pertemuan I dan II terjadi peningkatan aktivitas belajar yang sedikit menggembirakan. Jika pada pertemuan I rata-rata tingkat aktivitas siswa baru mencapai 41\%, maka pada pertemuan II tingkat aktivitas belajar siswa mencapai rata-rata $57 \%$.

Tabel 1. Distribusi Aktivitas Belajar Siswa Akhir Siklus 1 Pertemuan 1 \& II Metode Card Sort Untuk Meningkatkan Aktivitas Belajar pada Mata Pelajaran IPA Siswa Kelas VII SMP N 31 Batam.

\begin{tabular}{|c|c|c|c|c|c|c|}
\hline \multirow{3}{*}{ No } & \multirow{3}{*}{ Aktivitas siswa } & \multicolumn{5}{|c|}{ SIKLUS I } \\
\hline & & \multicolumn{2}{|c|}{ Pertemuan I } & \multicolumn{2}{|c|}{ Pertemuan II } & \multirow{2}{*}{$\begin{array}{c}\text { Total } \\
(\%)\end{array}$} \\
\hline & & Skor & $\%$ & Skor & $\%$ & \\
\hline 1 & Mengucapkan salam dan absensi & 10 & 60 & 13 & 78 & 18 \\
\hline 2 & $\begin{array}{l}\text { Mendengarkan penjelasan tentang materi } \\
\text { yang ditempel dipapan/ depan kelas }\end{array}$ & 7 & 42 & 10 & 60 & 18 \\
\hline 3 & $\begin{array}{l}\text { Mencari kartu dengan kategori/defenisi } \\
\text { yang sama }\end{array}$ & 10 & 60 & 12 & 72 & 12 \\
\hline 4 & $\begin{array}{l}\text { Berdiskusi dengan kalompok dan } \\
\text { presentase }\end{array}$ & 8 & 48 & 11 & 66 & 18 \\
\hline 5 & Menjawab pertanyaan dari siswa/guru & 7 & 42 & 12 & 72 & 30 \\
\hline 6 & Menulis kesimpulan pelajaran & 8 & 48 & 10 & 60 & 12 \\
\hline \multirow[t]{4}{*}{7} & $\begin{array}{l}\text { Menutup pelajaran dengan mengucapkan } \\
\text { salam }\end{array}$ & 8 & 48 & 12 & 72 & 24 \\
\hline & Jumlah & 58 & - & 80 & - & - \\
\hline & Rata-rata persentase & & $41 \%$ & & $57 \%$ & $19 \%$ \\
\hline & Klasifikasi & & & & ang & $(+)$ \\
\hline
\end{tabular}

Sumber : Pengolahan data lembar Observasi Aktivitas Siswa Siklus 1 Pertemuan II

\section{Refleksi 1.}

Dengan memperhatikan aktivitas yang telah ditunjukkan siswa diatas, maka berdasarkan hasil pembahasan peneliti dan observer terhadap pembelajaran pada siklus 1 pertemuan I-II ini terdapat beberapa kelemahan dalam pembelajaran yaitu masih perlu perbaikan dilakukan diantaranya : ada yang tidak mendengar karena guru tidak melihat kondisi kelas apakah anak-anak sudah siap/fokus untuk belajar. Penjelasan guru masih kurang secara keseluruhan sehingga pengolahan pembelajaran belum sesuai dengan tahap yang dimuat dalam Rencana Pelaksanaan Pembelajaran 2.

Guru masih kurang ketegasan dalam memberikan instruksi/pengarahan sehingga siswa masih ada yang tidak melakukan aktivitas untuk mencari kartu. Jika kita bandingkan hasil yang diperoleh pada siklus 2 pertemuan I ini dengan hasil akhir siklus I terjadi peningkatan sebesar $22 \%$ dari $57 \%$ menjadi $79 \%$ maka data peningkatan akan terlihat seperti Tabel 2.

Peningkatan aktivitas belajar yang diperoleh pada tahap ini meningkat dengan penambahan rata-rata $22 \%$, dari klasifikasi "rendah" dengan rata-rata tingkat aktivitasnya dari $57 \%$ menjadi $79 \%$. 
Tabel 2 Distribusi Aktivitas Belajar Siswa Akhir Siklus 1 Pertemuan 1 \& II dan Siklus 2 Pertemuan I Penggunaan Metode Card Sort Untuk Meningkatkan Aktivitas Belajar pada Mata Pelajaran IPA Siswa Kelas VII SMP N 31 Batam.

\begin{tabular}{|c|c|c|c|c|c|c|}
\hline \multirow{3}{*}{ No } & \multirow{3}{*}{ Aktivitas Siswa } & \multicolumn{5}{|c|}{ SIKLUS 2} \\
\hline & & \multicolumn{2}{|c|}{ Akhir Siklus I } & \multicolumn{2}{|c|}{ Siklus 2 Pertemuan 1} & \multirow{2}{*}{$\begin{array}{c}\text { Total } \\
(\%)\end{array}$} \\
\hline & & Skor & $\%$ & Skor & $\%$ & \\
\hline 1 & Mengucapkan salam dan absensi & 13 & 65 & 17 & 85 & 20 \\
\hline 2 & $\begin{array}{l}\text { Mendengarkan penjelasan } \\
\text { tentang materi yang ditempel } \\
\text { dipapan/depan kelas }\end{array}$ & 10 & 50 & 15 & 75 & 25 \\
\hline 3 & $\begin{array}{l}\text { Mencari kartu dengan } \\
\text { kategori/defenisi yang sama }\end{array}$ & 12 & 60 & 16 & 80 & 20 \\
\hline 4 & $\begin{array}{l}\text { Berdiskusi dengan kelompok } \\
\text { dan presentase }\end{array}$ & 11 & 55 & 15 & 75 & 20 \\
\hline 5 & $\begin{array}{l}\text { Menjawab pertanyaan dari } \\
\text { siswa/guru }\end{array}$ & 12 & 60 & 17 & 85 & 25 \\
\hline 6 & Menulis kesimpulan pelajaran & 10 & 50 & 14 & 70 & 20 \\
\hline 7 & $\begin{array}{l}\text { Menutup pelajaran dengan } \\
\text { mengucapkan salam }\end{array}$ & 12 & 60 & 17 & 85 & 25 \\
\hline & Jumlah & 80 & - & 111 & - & - \\
\hline & Rata-rata persentase & & $57 \%$ & & $79 \%$ & $22 \%$ \\
\hline & Klasifikasi & & & & & $(+)$ \\
\hline
\end{tabular}

\section{Refleksi 2.}

Dengan memperhatikan aktivitas belajar guru dan siswa yang diperoleh diatas, maka berdasarkan hasil pembahasan peneliti dan observer terhadap pembelajaran pada siklus 2 pertemuan I ini terdapat kelemahan yaitu Kelemahan-kelemahan diatas masih perlu perbaikan-perbaikan yang mesti dilakukan diantaranya : kartu yang bertuliskan materi yang ditempel dipapan/depan kelas, guru harus memberikan instruksi yang lengkap yaitu dengan memberitahukan kartu yang bertanda ceklis materi dan bertanda bintang pasangannya agar siswa lebih cepat dan tanggap mencari pasangan kartu. Jika kita bandingkan hasil yang diperoleh pada siklus 2 pertemuan I ini dan hasil pertemuan II yaitu dengan peningkatan sebesar $79 \%$ menjadi $101 \%$, disini sudah terlihat dari klasifikasi "sedang" menjadi klasifikasi "tinggi" maka data peningkatan akan terlihat seperti tabel berikut ini :

Tabel 3. Distribusi Aktivitas Belajar Siswa Akhir Siklus 2 Pertemuan 1 \& II Penggunaan Metode Card Sort Untuk Meningkatkan Aktivitas Belajar pada Mata Pelajaran IPA Siswa Kelas VII SMP N 31 Batam.

\begin{tabular}{|c|c|c|c|c|c|c|}
\hline \multirow{3}{*}{ No } & \multirow{3}{*}{ Aktivitas Siswa } & \multicolumn{5}{|c|}{ SIKLUS 2} \\
\hline & & \multicolumn{2}{|c|}{ Pertemuan I } & \multicolumn{2}{|c|}{ Pertemuan II } & \multirow{2}{*}{$\begin{array}{c}\text { Total } \\
(\%)\end{array}$} \\
\hline & & Skor & $\%$ & Skor & $\%$ & \\
\hline 1 & Mengucapkan salam dan absensi & 17 & 85 & 21 & 105 & 25 \\
\hline 2 & $\begin{array}{l}\text { Mendengarkan penjelasan } \\
\text { tentang materi yang ditempel } \\
\text { dipapan/depan kelas }\end{array}$ & 15 & 75 & 20 & 100 & 25 \\
\hline
\end{tabular}




\begin{tabular}{llccccc}
\hline 3 & $\begin{array}{l}\text { Mencari kartu dengan } \\
\text { kategori/defenisi yang sama }\end{array}$ & 16 & 80 & 21 & 105 & 25 \\
\hline 4 & $\begin{array}{l}\text { Berdiskusi dengan kalompok } \\
\text { dan presentase }\end{array}$ & 15 & 75 & 20 & 100 & 25 \\
\hline 5 & $\begin{array}{l}\text { Menjawab pertanyaan dari } \\
\text { siswa/guru }\end{array}$ & 17 & 85 & 19 & 95 & 25 \\
\hline 6 & Menulis kesimpulan pelajaran & 14 & 70 & 18 & 90 & 35 \\
\hline 7 & $\begin{array}{l}\text { Menutup pelajaran dengan } \\
\text { mengucapkan salam }\end{array}$ & 17 & 85 & 22 & 110 & 25 \\
$\quad$ Jumlah & $\mathbf{1 1 1}$ & - & $\mathbf{1 3 9}$ & - & - \\
\hline$\quad$ Rata-rata persentase & $\mathbf{7 9 \%}$ & $\mathbf{1 0 1 \%}$ & $\mathbf{2 6 \%}$ \\
\hline$\quad$ Klasifikasi & Sedang & Tinggi & $(+)$ \\
\hline
\end{tabular}

Sumber : Pengolahan data lembar Observasi Aktivitas Belajar Siswa Siklus 2 Pertemuan I dan II

Peningkatan aktivitas belajar siswa yang diperoleh pada tahap ini cukup membanggakan peneliti dengan rata-rata tingkat aktivitas dari 79\% (klasifikasi sedang) menjadi $101 \%$ (klasifikasi tinggi).

\section{Refleksi 3.}

Dengan memerhatikan aktivitas belajar siswa dan guru yang diperoleh siswa diatas, maka berdasarkan hasil pembahasan peneliti dan observer terhadap pembelajaran pada siklus 2 pertemuan II ini terdapat beberapa kelemahan yaitu dari hasil refleksi pertemuan II siklus 2 peneliti masih terus memberitahukan kepada guru melakukan perbaikan-perbaikan dalam melaksanakan proses pembelajaran seperti lebih menguasi tahapan-tahapan dalam RPP, lebih sungguh-sungguh dalam mengamati dan membimbing kegiatan siswa.

Dari pengamatan Tabel 4. tampak aktivitas siswa pertemuan I siklus 3 ini terjadi terus peningkatan terhadap semua indikator bahkan melebihi dari 100\%. Rata-rata tingkat aktivitas belajar yang dilakukan oleh siswa sudah mencapai 121. Dari pengamatan data diatas menunjukkan bahwa rata-rata tingkat aktivitas belajar siswa pada mata pelajaran IPA sudah mencapai ketuntasan (121\%), yaitu pada klasifikasi minimal "tinggi".

Tabel 4. Distribusi Aktivitas Belajar Siswa Akhir Siklus 3 Pertemuan 1 Penggunaan Metode Card Sort Untuk Meningkatkan Aktivitas Belajar pada Mata Pelajaran IPA Siswa Kelas VII SMP N 31 Batam.

\begin{tabular}{llcccccc}
\hline \multirow{2}{*}{ No } & \multicolumn{1}{c}{ Aktivitas Siswa } & \multicolumn{3}{c}{ SIKLUS 2 } & \multicolumn{2}{c}{ SIKLUS 3 } \\
\cline { 3 - 7 } & \multicolumn{2}{c}{ Pertemuan I } & \multicolumn{2}{c}{ Pertemuan II } & \multicolumn{2}{c}{ Pertemuan I } \\
\cline { 2 - 7 } & Skor & \% & Skor & \% & Skor & \% \\
\hline 1 & $\begin{array}{l}\text { Mengucapkan salam dan } \\
\text { absensi }\end{array}$ & 17 & 85 & 21 & 105 & 25 & 125 \\
\hline 2 & $\begin{array}{l}\text { Mendengarkan penjelasan } \\
\text { tentang materi yang }\end{array}$ & 15 & 75 & 20 & 100 & 24 & 120 \\
\hline
\end{tabular}




\begin{tabular}{|c|c|c|c|c|c|c|c|}
\hline & $\begin{array}{l}\text { ditempel dipapan/depan } \\
\text { kelas }\end{array}$ & & & & & & \\
\hline 3 & $\begin{array}{l}\text { Mencari kartu dengan } \\
\text { kategori/defenisi yang sama }\end{array}$ & 16 & 80 & 21 & 105 & 23 & 115 \\
\hline 4 & $\begin{array}{l}\text { Berdiskusi dengan } \\
\text { kalompok dan presentase }\end{array}$ & 15 & 75 & 20 & 100 & 24 & 120 \\
\hline 5 & $\begin{array}{l}\text { Menjawab pertanyaan dari } \\
\text { siswa/guru }\end{array}$ & 17 & 85 & 19 & 95 & 25 & 125 \\
\hline 6 & $\begin{array}{l}\text { Menulis kesimpulan } \\
\text { pelajaran }\end{array}$ & 14 & 70 & 18 & 90 & 24 & 120 \\
\hline 7 & $\begin{array}{l}\text { Menutup pelajaran dengan } \\
\text { mengucapkan salam }\end{array}$ & 17 & 85 & 22 & 110 & 25 & 125 \\
\hline & Jumlah & 111 & - & 139 & - & 170 & - \\
\hline & Rata-rata persentase & & $79 \%$ & & $101 \%$ & & $121 \%$ \\
\hline
\end{tabular}

Sumber : Pengolahan data lembar ObservasiI Aktivitas Belajar Siswa Siklus 3 Perte.I dan Siklus 2 Pertemuan II

Peningkatan yang terjadi dalam 3 siklus yang dilakukan penelitian ini terlihat dengan jelas dan sangat baik, Hal ini berarti bahwa penelitian ini berhasil dengan baik bahkan melebihi klasifikasi "minimal” yang diharapkan. Semua hasil yang diperoleh dalam pelaksanaan 3 siklus ini selalu mengalami peningkatan yang begitu signifikan. Lebih jelasnya dapat kita lihat pada grafik setelah hasil distribusi dibawah ini.

\section{Refleksi 4.}

Dengan memperhatikan aktivitas belajar siswa dan guru yang telah ditunjukkan dan dicapai siswa diatas, serta berdasarkan hasil pembahasan peneliti dan observer penelitian dihentikan sampai disini. Aktivitas belajar yang telah ditunjukkan siswa sangat menggembirakan dan memuaskan semua pihak. Hal ini jelas menunjukkan bakwa penelitian ini berhasil dengan baik.

\section{PEMBAHASAN}

Hasil pembahasan pada siklus I, 2 dan siklus 3, untuk aktivitas guru yang diamati pada siklus 1 dengan perolehan skor dari 28 (70\%) dengan klasifikasi kurang sempurna menjadi skor $30(75 \%)$ dan klasifikasi kurang sempurna dan pada siklus 2 pertemuan I mengalami peningkatan skor menjadi 35 (88\%), yaitu klasifikasi sempurna, namun diakhir siklus 2 menjadi 40 (101\%) dengan klasifikasi sempurna dan pada akhir siklus 3 terjadi lagi peningkatan skor sangat tinggi menjadi 44 (110\%) dengan klasifikasi sangat sempurna seperti yang tertera pada tabel berikut: 
Darlianty, Lani Puspita dan Destaria Sudirman : Implementasi Metode Card....

Tabel 5. Distribusi Aktivitas Guru dalam Menggunakan Metode Card Sort

\begin{tabular}{cccccccccccc}
\hline & & \multicolumn{4}{c}{ SIKLUS 1 } & \multicolumn{3}{c}{ SIKLUS 2 } & \multicolumn{2}{c}{ SIKLUS 3 } \\
\cline { 3 - 12 } No & \multirow{2}{*}{ Klasifikasi } & \multicolumn{2}{c}{ Pertemuan I } & \multicolumn{2}{c}{ Pertemuan II } & \multicolumn{2}{c}{ Pertemuan I } & Pertemuan II & \multicolumn{2}{c}{ Pertemuan I } \\
\cline { 3 - 12 } & & Skor & \% & Skor & \% & Skor & \% & Skor & \% & Skor & \% \\
\hline 1 & Sangat Sempurna & 0 & - & 0 & - & 10 & $25 \%$ & 15 & $38 \%$ & 20 & $50 \%$ \\
\hline 2 & Sempurna & 8 & $20 \%$ & 8 & $20 \%$ & 8 & $20 \%$ & 16 & $40 \%$ & 24 & $60 \%$ \\
\hline 3 & $\begin{array}{c}\text { Kurang } \\
\text { Sempurna }\end{array}$ & 12 & $30 \%$ & 18 & $45 \%$ & 15 & $38 \%$ & 9 & $23 \%$ & 0 & - \\
\hline 4 & Tidak Sempurna & 8 & $20 \%$ & 4 & $10 \%$ & 2 & $5 \%$ & 0 & - & 0 & - \\
\hline 5 & $\begin{array}{c}\text { Tidak } \\
\text { Dilaksanakan }\end{array}$ & 0 & - & 0 & - & 0 & - & 0 & - & 0 & - \\
\hline & Jumlah & $\mathbf{2 8}$ & $\mathbf{7 0 \%}$ & $\mathbf{3 0}$ & $\mathbf{7 5 \%}$ & $\mathbf{3 5}$ & $\mathbf{8 8 \%}$ & $\mathbf{4 0}$ & $\mathbf{1 0 1}$ & $\mathbf{4 4}$ & $\mathbf{1 1 0 \%}$ \\
\hline
\end{tabular}

Sumber : Pengolahan Data Lembar Observasi Aktivitas Guru Siklus 1, Siklus 2 dan Siklus 3.

Untuk aktivitas siswa pertemuan pada siklus 1 mengalami peningkatan jumlah skor dari 58 dengan rata-rata persentase $41 \%$ (klasifikasi rendah) menjadi skor 80 dengan rata-rata persentase 57\% (klasifikasi sedang) dan pada perolehan skor 111 dengan rata-rata $79 \%$ (klasifikasi sedang) pada pertemuan siklus 2 juga meningkat tetapi sudah mencapai pada skor 139 dengan rata-rata persentase 101\% (klasifikasi tinggi), Dan pada siklus 3 ini sudah jelas terlihat tetap meningkat dengan perolehan skor 170 pada rata-rata persentase $121 \%$ yaitu pada (klasifikasi sangat tinggi) seperti yang tertera pada tabel dibawah ini:

Tabel 6. Distribusi Aktivitas Siswa Dalam Pembelajaran Menggunakan Metode Card Sort

\begin{tabular}{|c|c|c|c|c|c|c|c|c|c|c|c|}
\hline \multirow{3}{*}{ No } & \multirow{3}{*}{ Klasifikasi } & \multicolumn{4}{|c|}{ SIKLUS 1} & \multicolumn{4}{|c|}{ SIKLUS 2} & \multirow{2}{*}{\multicolumn{2}{|c|}{$\begin{array}{c}\text { SIKLUS 3 } \\
\text { Pertemuan } \\
\text { I }\end{array}$}} \\
\hline & & \multicolumn{2}{|c|}{$\begin{array}{c}\text { Pertemuan } \\
\text { I }\end{array}$} & \multicolumn{2}{|c|}{ Pertemuan II } & \multicolumn{2}{|c|}{$\begin{array}{c}\text { Pertemuan } \\
\text { I }\end{array}$} & \multicolumn{2}{|c|}{$\begin{array}{c}\text { Pertemuan } \\
\text { II }\end{array}$} & & \\
\hline & & Skor & $\%$ & Skor & $\%$ & Skor & $\%$ & Skor & $\%$ & Skor & $\%$ \\
\hline 1 & $\begin{array}{l}\text { Mengucapkan salam } \\
\text { dan absensi }\end{array}$ & 10 & 50 & 13 & 65 & 17 & 85 & 21 & 110 & 25 & 125 \\
\hline 2 & $\begin{array}{l}\text { Mendengarkan } \\
\text { penjelasan tentang } \\
\text { materi yang ditempel } \\
\text { di papan/depan kelas }\end{array}$ & 7 & 35 & 10 & 50 & 15 & 75 & 20 & 100 & 24 & 120 \\
\hline 3 & $\begin{array}{l}\text { Mencari kartu dengan } \\
\text { kategori/defenisi } \\
\text { yang sama }\end{array}$ & 10 & 50 & 12 & 60 & 16 & 80 & 21 & 105 & 23 & 115 \\
\hline 4 & $\begin{array}{l}\text { Berdiskusi dengan } \\
\text { kalompok dan } \\
\text { presentase }\end{array}$ & 8 & 40 & 11 & 55 & 15 & 75 & 20 & 100 & 24 & 120 \\
\hline 5 & $\begin{array}{l}\text { Menjawab pertenyaan } \\
\text { dari siswa/guru }\end{array}$ & 7 & 35 & 12 & 60 & 17 & 85 & 19 & 95 & 25 & 125 \\
\hline 6 & $\begin{array}{l}\text { Menulis kesimpulan } \\
\text { pelajaran }\end{array}$ & 8 & 40 & 10 & 50 & 14 & 70 & 18 & 90 & 24 & 120 \\
\hline
\end{tabular}




\begin{tabular}{|c|c|c|c|c|c|c|c|c|c|c|c|}
\hline 7 & $\begin{array}{l}\text { Menutup pelajaran } \\
\text { dengan mengucapkan } \\
\text { salam }\end{array}$ & 8 & 40 & 12 & 60 & 17 & 85 & 22 & 110 & 25 & 125 \\
\hline & JUMLAH & 58 & - & 80 & - & 111 & - & 139 & - & 170 & \\
\hline & RATA-RATA & - & $41 \%$ & - & $57 \%$ & - & $\begin{array}{l}79 \\
\%\end{array}$ & - & $\begin{array}{c}101 \\
\%\end{array}$ & - & $\begin{array}{c}121 \\
\%\end{array}$ \\
\hline & KLASIFIKASI & & dah & & ing & Sec & & & & & \\
\hline
\end{tabular}

Sumber : Pengolaan Data Lembar Observasi Aktivitas Siswa Siklus 1, Siklus 2 dan Siklus 3.

Semua hasil yang diperoleh dalam pelaksanaan tiga siklus ini selalu mengalami peningkatan yang begitu signifikan. Untuk lebih jelasnya dapat kita lihat pada grafik dibawah ini :

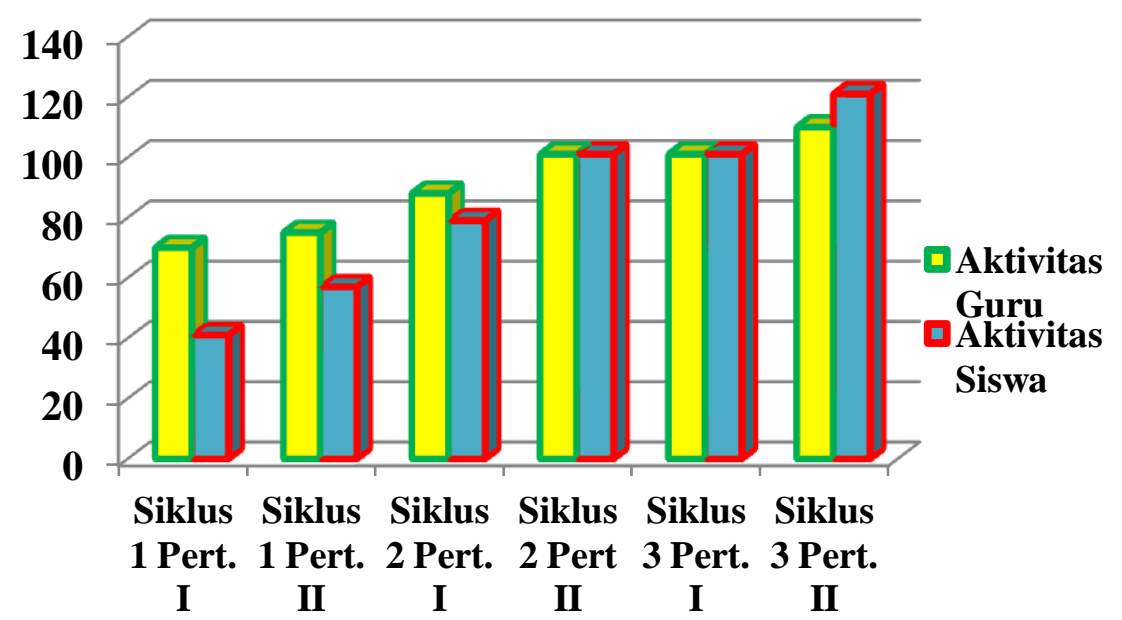

Grafik 1. Aktivitas Guru dan Siswa pada Siklus 1, Siklus 2 dan Siklus 3 Implementasi metode Card Sort untuk meningkatkan Aktivitas Belajar Siswa Pada Mata Pelajaran IPA Siswa Kelas VII SMP Negeri 31 Batam.

Hasil yang diperoleh sesuai dengan ungkapan (Yasin A Fattah. 2008), yang menyatakan bahwa metode Card Sort dapat mengoptimalkan pemahaman siswa pada mata pelajaran Biologi artinya metode Card Sort dapat memberikan penjelasan tentang materi yang diberikan guru kepada siswa sehingga siswa menjadi mengerti dengan apa yang sedang dan telah dipelajarinya. Dengan begitu aktivitas belajar guru dan siswa semakin baik dan tentunya akan diiringi oleh hasil belajar yang baik pula serta sangat menyenangkan semua pihak. Dengan demikian tindakan lebih lanjut dari hasil penelitian membuktikan bahwa hipotesis penelitian yang berbunyi: "Dengan diterapkan Metode Card Sort dapat meningkatkan aktivitas belajar pada mata pelajaran IPA siswa kelas VII SMP Negeri 31 Batam Kecamatam Batam Kota Tahun Pelajaran 2013/2014”. 


\section{KESIMPULAN}

Aktivitas guru meningkat pada setiap siklus dalam setiap pertemuannya dari perolehan skor 28 menjadi 30 dengan klasifikasi kurang sempurna, pada siklus 2 dari skor 35 menjadi 40 dengan klasifikasi kurang sempurna menjadi sempurna, dan pada siklus 3 dari skor 40 menjadi 44 dengan klasifikasi sempurna menjadi klasifikasi sangat sempurna. Aktivitas siswa juga mengalami peningkatan dari klasifikasi rendah menjadi klasifikasi sedang dengan perolehan skor 58 menjadi skor 80 pada siklus 1 , begitu juga dari klasifikasi sedang menjadi klasifikasi tinggi dengan perolehan skor 111 menjadi skor 139 pada siklus 2 dan pada siklus 3 dari klasifikasi tinggi menjadi klasifikasi sangat tinggi dengan perolehan skor 139 menjadi skor 170.

\section{REFERENSI}

A.M, Sardiman.2007. Interaksi Belajar Mengajar. Raja Grafindo, Jakarta.

Gimin, Dkk. 2008. Instrumen dan Pelaporan hasil Penelitian Tindakan Kelas. Makalah Pelatihan, Pekanbaru.

Hamalik, Oemar. 2002. Psikologi Belajar dan Mengajar. Sinar Baru, Bandung.

Jessica. 2009. Pengertian Belajar. htt://techonly13.wordpress.com. Diakses 4 Juli 2009.

Kunandar. 2011. Langkah Mudah Penelitian Tindakan Kelas Sebagai Pengembangan Profesi Guru. Rajawali Pers, Jakarta.

Mulyono, Anton. 2001. Kamus Besar Indonesia. Balai Pustaka, Jakarta

M. Sobri Sutikno. 2009. Pengelolaan Pendidikan. Prospect, Bandung.

Rosalia, Tara. 2005. Aktivitas Belajar. htt://id.hvoong.com. Diakses 27 Januari 2011.

Rochmanata Wijaya. 2002. Penelitian untuk Ilmi-ilmu Perilaku. Remaja Rosda Karya, Bandung.

Ruslan Rusdy. 2003. Konsep Metodologi Penelitian Pendidikan. PT. Raja Grafindo Persada, Jakarta.

Sanjaya , Wina. 2009. Penelitian Tindakan Kelas, Kencana Prenada Media Group, Jakarta.

Tim Abdi Guru. 2012. IPA Terpadu SMP/MTS. Penerbit Erlangga, Jakarta.

Yasin A Fattah. 2008. Metode Card Sort. http://lib.uin-malang.ac.id. Diakses 12 Agustus 2009. 